\title{
"It's strange what you don't forget": Towards a Postmodern White Female Identity in Jayne Anne Phillips's Machine Dreams
}

\section{Pirjo Aholkas}

University of Turku

\begin{abstract}
This article discusses the female identity construction of the daughter. figure in Jayne Anne Phillips's Machine Dreams (1984). It looks at the novel through the lens of contemporary feminist theory, which utilizes insights fiom postmodern and poststructuralist thought. Moreover, the analysis draws on critical studies of whiteness. It argues that fragments of family history reveal the decisive influence of intersecting discourses of gender, ethnicity, "race," class and sexuality on the formation of the protagonist's emerging identity. Instead of settling for a pre-given and coherent identity, she tries to create an alternative identity reminiscent of postmodern formations, which are characterized by heterogeneity, openness, and fluidity. The middle-class identities, which are produced in a performative manner within the context of regulatory norms imposed by the dominant society, constantly reiterate the gender ideals of sedimented heterosexuality. In drawing attention to the power differences among whites, while still employing stereotyped depictions to delimit the borders of white middle-class identity, the novel helps to challenge essentialized notions of white female identity. Even if the protagonist's new identity appears to be potentially subversive, it remains highly problematic.'
\end{abstract}

Key words: American literature - Jayne Anne Phillips - identity - postmodern feminisms - performativity - heteronormativity - myths of Southern womanhood "race" and ethnicity - class - whitenesses

Jayne Anne Phillips, the author of the widely acclaimed Machine Dreams (1984), left her home state West Virginia shortly after college and has 
lived most of her life away from the South. Nevertheless, she speaks about the continuing importance of West Virginia and the Appalachian region for her fiction. In addition to frequently using her home state as the setting of her fiction, she engages a number of themes which have been regarded as typical of Southern women's writing. They include the profound importance of the family in Southern life and the ways in which regional and cultural forces have shaped the experience of Southern women. No wonder critics still regard her as a Southern writer. ${ }^{2}$ Many of the short stories published by Phillips prior to Machine Dreams, her début novel, deal with lonely young women and adolescent girls. Even though her highly acclaimed collection Black Tickets (1979) depicts young drug addicts, prostitutes, and strippers, it also contains stories portraying the deep roots of regional family life. In a similar vein as some of the stories in Phillips's subsequent collection Fast Lanes (1983; expanded edition, 1989), the stories in Black Tickets share themes, characters, and incidents with Machine Dreams. Exploring the complexity and fragility of inescapable family ties, these stories invoke a strong sense of place.

Since Machine Dreams, Phillips has published another two novels: Shelter (1994) and MotherKind (2000). Both books address white female identity, but are tighter and have a smaller scope than her début novel. Like the female protagonists at the end of Machine Dreams and Shelter, respectively, the adult poet-protagonist of MotherKind is a migrant daughter from the South. Together with Machine Dreams and Shelter, MotherKind contributes to Phillips's examination of the multiple and intersecting nature of white women's identity formation. Even though the female protagonists of her carefully patterned novels move away from West Virginia, it is through memory and dream sequences that their concern with new subject positions remains linked to a process of negotiating their past in the places of their birth

2. In his Southern Writer and the Postmodern World, Fred Hobson refers to Phillips as a Southern writer but he also argues against this claim: "Just what is southern and what is not, which writers are southern and which are not, is a continuing problem for the student of Southern literature. One thinks of Jayne Anne Phillips, author of Machine Dreams and Black Tickets, a writer generally assigned as 'Southern.' But Phillips was born and grew up in northeastern West Virginia, was educated in Morgantown (much closer to Pittsburgh than anything Southern), and writes about an area that has more in common with Pennsylvania than, say, Virginia" (Hobson 108 n. 3). 
Machine Dreams ${ }^{3}$ is set in West Virginia and is a deftly crafted retrospective narrative consisting of individual memories and dreams of four members of a "nuclear" family - the Hampsons. The novel spans from the Depression years until the Vietnam War, yet defies linear time with its rapid shifts of setting and focalization. It is no wonder, therefore, that Machine Dreams has been connected to postmodern writing. In this article, I will adopt a retrospective approach, looking at Phillips's début novel through the lens of contemporary feminist theory which utilizes insights from postmodern and poststructuralist thought. Ultimately, Phillips's subtly constructed novel centers on the identity formation of Danner, the daughter figure. Instead of settling for a pre-given and stable identity rooted in family and community, Danner tries to create a new identity suggestive of postmodern female identity formations, which are characterized by openness, fluidity and flux. ${ }^{4}$ My examination of Danner's identity process is based on postmodern feminist theories, which replace unitary and fixed "notions of woman and feminine gender identity with plural and complexly constructed conceptions" of cultural identity in which gender intersects "with multiple other axis on identity" (see, for instance, Bordo 139; Fraser and Nicholson 35; Lloyd 15). Identities are produced within existing power structures, but postmodern thought in general and postmodern feminisms in particular deconstruct subordinating norms and insist on recognizing and respecting difference. Thus, like feminisms of color and ethnicity, postmodern feminist approaches, which include theories of performativity, are useful in challenging dominant regimes of categorization and oppression.

According to performative theory, subjects are constructed through the reiteration of dominant norms. Gaps and fissures may be revealed as constitutive instabilities, however, in the process of the repetition of regulatory norms (Butler 9-10), helping to create space for postmodern identity formations. Phillips's novel situates constructions of gender in relation to other identity categorizations. Hence I will probe how fragments of his-

3. Hereafter cited parenthetically in the main text and abbreviated as MD.

4. In Beyond Identity Politics: Feminism, Power \& Politics, Moya Lloyd examines various different accounts of processual feminist subject formations. She names theorists working on multiple and shifting subjectivity and who focus on identity differences as "critics of the subject-in-process." Lloyd concentrates on feminist theorists working in the Anglophone world and refers to "thinkers as diverse as Judith Butler, Chantal Mouffe, Donna Haraway, Diana Fuss, Shane Phelan, and many others." See Lloyd 6, 8, 10. 
tory of the Hampson family reveal the decisive influence of intersecting discourses of gender, ethnicity, "race," class, and sexuality on the formation of Danner's emerging female subjectivity. The fictional family members in Machine Dreams take their Americanness for granted and epitomize the ideals of the dominant Anglo-Saxon Protestant culture. Yet, the novel shows that this Americanness, which is linked to the dominant narrative of nation, is always in the process of being made. In my reading of Phillips's novel, therefore, I will draw on critical studies of whiteness which analyze the practices of white skin privilege. In the context of Machine Dreams, postmodern feminist thought not only sheds light on the young protagonist's identity process, but also on how she slowly becomes aware of the impact that complicated power hierarchies have on her growing sense of female agency. Danner's development as an individual is equally affected by the intertwined discourses of place and family. While superficially conforming to the stifling local norms of small-town Southern America in the 1950s and 1960s, she constantly dreams of being liberated from their restrictive reality. Danner's increasing awareness of the complex nature of family relationships enables her to distance herself from the mindset and customs of her home town and to begin to define herself outside her family. My discussion of this aspect of Danner's identity formation is informed by contemporary feminist research on the family.

The early reception of Machine Dreams fitted into a tradition associating West Virginia with the Garden of Eden. Admittedly, the novel is tinged with nostalgia for the innocence of a lost childhood world, but it also sustains a questioning attitude towards family history. The disappearance of Billy, Danner's younger brother, in the Vietnam War offers the catalyst for the retrospective narrative, with flashbacks to the protagonists' childhood and youth. Gradually, the novel's fragmentary narrative structure is revealed to be part of Danner's reconstruction of the family's past through interviews she conducts after the family has been told that Billy is missing in action. In doing this, Machine Dreams is reminiscent of "memory work," an active practice of remembering which consciously seeks to bring to light the forgotten or the repressed (Kuhn 186). Furthermore, family storytelling can be seen as a privileged site of personal identity performance, which provides the opportunity to resist idealized versions of family and complicates the dominant narrative of nation (Lan- 
gellier and Peterson 112-113, 155). Significantly enough, the gaps revealed in the performance of the Hampson family narrative disrupt the comforts of the familiar and thereby provide the opportunity for a critical rereading of past events. Focusing on Danner's identity construction, my investigation of Machine Dreams highlights the questioning and subversive potential of the novel.

\section{"Racing" and Gendering the Hampson Family Members}

The so-called nuclear version of the family, which the Hampsons represent, was born by the end of the eighteenth century and has been identified as a white middle-class construct. It was elevated to the status of an ideal in America in the 1950s and 1960s, the two decades which are captured in the sections depicting Danner's childhood and teen years in Phillips's novel. In traditional representations of nuclear families, a white mother figure embodies a nurturing and caring ideal. This matches the portrayal of Jean, the mother figure in Machine Dreams, whose loving devotion is of great significance in Danner's identity formation. The novel opens with the reminiscences of Jean, who is mindful of middleclass proprieties and social stability. In talking about her own youth, she gently reproaches Danner for her restlessness: "Look at you - born here and think you have to get to California, go so far, do so much" (MD 15). Danner's dream about setting out for California is a clue to her desire to challenge the status quo and mores of her home town.

The status quo of Bellington, Danner's home town, depends to a large extent on the inhabitants' internalization of traditional gender roles. Since the concept of the nuclear family is premised on traditional gender roles, feminist scholars recognize representations of the nuclear group as ideological vehicles (Boose and Flowers 3, 5). Moreover, recent studies approach the nuclear model as an important site of performativity through which gender and sexuality are reproduced (Chambers 11, 169; see also 29). In Phillips's narrative reworking of the modern nuclear model, the fictional members of the Hampson family cite and reiterate the heterosexual family as a key regulatory discourse of their lives. However, an implicit critique of the white middle-class model as a universalized myth- 
ical norm can be detected throughout Machine Dreams. Indeed, the idea of the modern nuclear family is actually questioned by the subjects who personify the dominant family discourse in the novel. What is more, the novel abounds in broken families, yet, it is only retrospectively that the narrated family events are understood to be significant for Danner's identity construction as a provisional and continuous process of gendering, classing, and "racing."

Nuclear families were constructed on the basis of white heteronormativity. In spite of the burden of Southern racial history and the complex relationship between race and gender in the region, Fred Hobson points out that, during the late1960s, social movements such as the civil rights movement, in particular, brought about a "a watershed in southern thought" (7). As regards Southern literature, however, it has been argued that scholars have until recently conflated "Southern" and "white," and have drawn on a male-defined Southern tradition (Yaeger 49). By contrast, Rebecca Aanerud rightly claims that race is a meaningful factor in every individual life. She draws on Toni Morrison's Playing in the Dark to argue that unless told otherwise, non-defined whiteness is a type of marking and calls this assumption "Morrison's method of white racial identification" (see 37, 39). Even though the white characters in Phillips's novel are not overtly described as white, they are clearly recognizable by this method. Moreover, throughout Machine Dreams, the whiteness of the enlarged family is emphasized by metaphorical use of the color white, whereas all the fictional characters who vary from the implicit white norm are overtly racially marked. For instance, the only racially identified boy scouts in the fictional festival parade scene in the novel are "[t]wo Negro boys in the fourth row" (MD 193). In addition, the different groups of white people - such as middle-class, working class, and poor whites - are also distinguished from one another.

Since race and gender are intertwined, the whiteness of characters in Phillips's novel is inextricably tied to their gender construction and sexuality. The most influential people in Danner's life are her family members. Consequently, the gender identity and racial identification of her father figure, Mitch Hampson, and her mother figure, Jean Hampson, are equally crucial for her own identity process. Mitch was born into a family where the men used to be household farmers and worked in the mines. He experiences first-hand how the local area turns into ghost towns and the 
previously beautiful Hampson farm becomes "heaps of dirt, cut-away ledges where they'd stripped" (MD 53) as a result of strip-mining. Subsequently, this negatively affects his sense of masculinity. Moreover, the broader process of American nation-building also contributes to Mitch's construction of his own masculinity. He was a young man in the 1930s, when there was a large-scale federal effort, as part of the New Deal, to restore the nation's manhood. Ultimately, the ideal man which American youths were expected to emulate embodied a white Anglo-Saxon ideal (Simon 151). In historical terms, the story of white America can be traced to the early settler colonialists, who identified themselves as AngloSaxon and justified their westward expansion by naming putative others as inferior (Frankenberg 12-13). Anglo-Saxon ideals also seem to be in conformity with the thesis according to which the mountain region had originally been settled by "pure Anglo-Saxon stock" (Whisnant 8). Although the Anglo-Saxon myth is not mentioned in Machine Dreams, Mitch is proud of the fact that "Hampsons had been in that valley a hundred years with just their neighbors" (MD 28). This statement implies that isolation has kept his home town and its surroundings unmixed generation after generation (cf. Whisnant 8), and therefore that the members of Mitch's family are the true inheritors of Anglo-Saxon superiority.

Despite claims asserting the region's ethnic homogeneity, Appalachia has long had its own minorities. A few blacks lived there prior to the Civil War, and industrialization brought immigrants from South and east Europe to the region at the turn of the $20^{\text {th }}$ century. Like Machine Dreams, Denise Giardina's novel, The Unquiet Earth (1992), depicts a young girl's coming of age in postwar West Virginia. The ethno-racial heterogeneity of the local inhabitants seems to be more pronounced in the mining towns of Giardina's book, whereas in Phillips's novel, as in real life, there are also a number of minor characters who represent various marginalized ethnicities and racialized groups. Stories about Mitch's youth include instances of Orientalism. In them, he tries to maintain his masculine identity by establishing a border between himself and his othered "not-self." It is small wonder, therefore, that Phillips's father figure uses his white heritage to prop up his sense of self in the presence of members of any other group.

In nineteenth-century America, less desirable immigrants, including those from Ireland, were "blackened" (Roediger 107, 133-4). Mitch 
comes to harbor a belated racial prejudice against what he regards as the "not-quite-white" Irish population, which includes his wife. Identifying the Irish, whose racial status was ambiguous in the larger culture in the nineteenth century, with racialized African Americans and Indians Mitch marks them as inferiors, which strengthens his sense of white masculine privilege. It is precisely for this reason that he even dislikes his children's tans: "You kids tan dark as Indians; you can thank your mother's Black Irish blood" (MD 191). As for Danner, it is interesting to note the extent to which her perceptions regarding race differ from those of her father. She identifies, for example, with the black protest marchers attacked by police dogs in Birmingham, Alabama, and begins to ponder why the black protests are not discussed in her social studies class. Unlike Mitch, Danner resists fixed notions of ethnic and racial identity and her thoughts contain a strong sense of social injustice.

As might be expected, race and gender also intersect in the female identity constructions of Danner and her mother. Hence a few words are in order here regarding the sociohistorical context in which Southern women's identity processes have developed. Historically, the gender roles of Southern women were strongly influenced by slavery. The myth of white Southern womanhood, which originally only applied to the daughters of the privileged planter class (Seidel 430), defined their perception of skin color. Rooted in the antebellum "cult of true womanhood," the proper role for nineteenth-century white Southern women emphasized the possession of "the cardinal virtues of piety, purity, submissiveness and domesticity" (see Welter 152; Carby 23). In spite of the fact that the white myth of Southern womanhood was heavily criticized from the start, literary scholars argue that Southern women writers still struggle with its legacy (Seidel 429, 432; Jones 279). No wonder, then, that the cost of succumbing to residual myths defining white Southern women in Machine Dreams is also visible in the ways in which Jean and Danner perform white middle-class femininity.

Jean's adherence to feminine behavior - reminiscent of the "cult of true womanhood" - is tied to her class background. When Jean was a small child, her father was wealthy and the family owned a big house in a street which is significantly "referred to as Quality Hill" (MD 3). Furthermore, memory fragments from the time when Jean and Mitch are courting and marry reveal that Jean not only thinks that his behavior 
affirms the complementary white Southern gender roles, but also casts her older suitor as "a perfect gentleman" (MD 16). Even before their marriage Mitch's masculinity undergoes many changes related to his social and historical circumstances. Indeed, as Brian Jarvis notes, his personal history "can be interpreted as a microcosmic representation of aspects of his culture's geographical development between 1910 and 1970" (1998: 95). In spite of the fact that Mitch becomes the co-owner of a concrete plant, his places of work are associated with the historically racialized Southern working class (Godden 251, 253), and Jean's increasing dissatisfaction with her husband appears to be linked to their diverging social aspirations.

One of the fragments from the past which exposes the Hampson family's ongoing class and gender competitiveness is the naming of Danner. Importantly, when discussing gender performativity, Judith Butler points out that fictional names can be seen as dynamic sites of identification (143). The narrator of Machine Dreams shares her insight, when she points to the convergence of class and gender in the name chosen by Jean, who wants to affiliate her daughter with her own family background. As Butler claims, names are tokens of the symbolic order and women's names are "always dependent on the social exigencies of paternity and marriage" $(152,153)$. It is precisely for this reason that Jean's decision to name her daughter after her mother's family can be interpreted as questioning a continued sense of patrilineality. As becomes clear in a conversation between Jean and one of her friends, Danner's name not only links her to her maternal grandmother, but also denotes a strong sense of class identification: "Stubborn and mannered as hell. Danners could be poor as church mice and walk around like heiresses" (MD 122). In addition, the racial interpellations implicit in the name are reinforced by a reference to Gracie, Jean's mother. Gracie seems to have internalized her fears about ethnic difference, and early in the novel she playfully calls Jean, who also tans easily, "her pickaninny" (MD 2). When Jean answers her friend by alluding to Gracie as an embodiment of "the Danner women," it is evident that, as a site of identification, the family name, which Danner receives as a first name, also has racial connotations. It is not only meant to invoke Danner's maternal and class identification but also to affirm her white identity.

At this point, it seems necessary to keep in mind that the founding 
interpellation of gender takes place at birth, that is before naming, and is reiterated at various points of the gendering process (Butler 7-8). As I have already indicated, the 1950 s, when Danner was a child, was a conservative time, when traditional gender norms were deeply ensconced in the United States. Phillips's representation of the gendering process of the main characters depicts how it develops through the inculcation of hegemonic social norms at home and in the local community. Nevertheless, as Brian Jarvis claims: "Phillips consistently eschews a grand narrative of the American family and even when her figurations appear to converge with dominant definitions they tend to work toward the deconstruction of the patriarchal chimera" (2001: 198). Dominant heteronormativity and compulsory heterosexuality are two socially produced discursive formations, which participate in the construction of gender and sexual identity. While heteronormativity and compulsory heterosexuality play an important role in Danner's teenage life, there are moments in her childhood that, contrary to Butler's notions about early gendering, seem to question the ubiquity of the dominant gendering and sexing practices. For example, there are two instances in Machine Dreams which show that Danner and Billy, even as children, are searching for alternatives to the fixed gendered identities performed by the white adults around them.

As very small children Danner and Billy hid from their parents in adjacent closets. In their separate closets, he wears a cap like his father's and she holds her mother's purse, but they signify their unbroken bond by tapping messages to each other on the wall between them. With its Freudian symbols of masculinity and femininity, this episode brings to mind Jacques Lacan's rethinking of Saussure's equation of signifier and signified, in which two toilet doors assign gender roles (see, for instance, Wright 1984: 109-10, and Wright 1986: 151). While Lacan's example shows that signifiers are not linked to fixed signifieds or concepts, the closet episode in Machine Dreams can be interpreted as suggesting the possibility of an alternative repetition of dominant gender scripts for masculinity and femininity. This is owing to the fact that the siblings keep communicating with each other. The second episode occurs towards the end of the novel, when Danner begins to understand the symbolic meaning of the secret passage she and Billy looked for in the compact house their father had built. The prospect of a temporary escape from these constrictive social norms points to the possibility of resistance and 
destabilization of these norms. Despite all the restrictions placed on individuals by the modern nuclear family and the normative values of status quo in postwar American society, Phillips's novel hints at alternative ways of enacting the racial and gender identities of her white protagonists.

\section{Sexualizing Danner's Subjectivity}

During slavery, skin color emerged as a significant factor defining women's sexuality. Black women were excluded from the female roles glorified within the discourse of the cult of true womanhood, but their sexuality was used to define its borders (Carby 30). There are also two interdependent codes of female sexuality in Machine Dreams: white middle-class women are depicted as pure and virtuous, whereas poor white women, or "white trash," mark the borders of whiteness and are stereotyped as representing dangerous and excessive sexuality (cf. Newitz and Wray 167). In Jean's and Mitch's generation, Marthella Bartnett, epitomizes "dangerous" poor white women who live in shanty houses. She is not only racialized as a poor white but her family is also linked to marginalized mixed-race groups: "Marthella was a dark little thing - the family had guinea blood, or Indian" (MD 45). Marked out as white trash, Marthella represents "something that must be discarded, expelled, and disposed of for whiteness to achieve and maintain social dominance" (Newitz and Wray 167). Revealingly, when Jean sees Marthella for the first time, she immediately detects her class background from her sexually provocative performance of femininity. It is only later that Jean seems to realize that she is encouraging a double standard by placing herself on a pedestal as a morally superior and sexually modest white middle-class woman. Yet, she instills submissiveness as a feminine virtue into her daughter's mind:

Danner hears Jean's voice as one continuous sound weaving through days and nights. Pretty is as pretty does, seen and not heard, my only darling, don't ever talk back to your own mother; come and read Black Beauty, a little girl with a crooked part looks like no one loves her [. . .] (MD 148). 
Indeed, the same myths of white womanhood which Jean has internalized play a pivotal role in Danner's early construction of her white heterosexual femininity.

The white middle-class discourse governing gender-appropriate heterosexual behavior was not only important for the family ideology in the postwar years, but also for the middle-class dating system that flourished as a modern form of courtship between roughly 1920 and 1965 (Bailey 3 ). The rules and conventions that grew up to regulate the new dating system in the twentieth century required that men always assume control whereas women were socialized to act as men's dependents (Bailey 3, 23-24). The Strawberry Festival, which takes place in Machine Dreams at a time when Danner and Billy are beginning to contemplate dating the opposite sex, offers a fictional arena for understanding the elaborate codes of dominant American constructions of masculinity and femininity in the postwar era of middle-class consensus. Indeed, the depiction of the festival, with its Radio Parade and the Mayor's pool party, speaks volumes as concerns the fictional siblings' gendering and sexualization through exclusionary means within the heterosexual matrix.

In the cold war years, over-protective and overindulgent mothers were accused of pampering their sons, thereby thwarting their masculine development (see, for instance, May 84). The association of subordinated masculinities, such as homosexuality, with femininity is a common feature of male gender oppression. The Boy Scouts' parade scene demonstrates how scouting provided an opportunity for little boys, like Billy, to counteract the seemingly prevalent forces of feminization at home and at school. While the parade, in which Billy is expected to participate the following year, marks a young boy's initiation into "mainstream" American masculinity, the narrator also emphasizes the Boy Scouts' crew cuts and khaki caps in order to hint at the military nature of the movement. Moreover, even if the boys' badges and yellow scarves strike Phillips's protagonist as feminine, she associates their eagle pins with those found on Army uniforms or military seals. In this way the narrator foreshadows Billy's participation in the Vietnam War. The feminine side of the idealized heterosexual dyad is symbolized by the Queen's court floats in the parade, which are always "purely white" (MD 194). Ironically, they resemble "an awkward herd of mechanical cakes tiered with girls in gowns and children in white bowers" (MD 194). Even as a young teen- 
ager, Danner's attempt to construct an alternative white female identity clearly involves exploring the transformative possibilities of gender flexibility. Is it any wonder that she would not only like Billy to resist a dominant construction of masculinity, but is also even more reluctant to perform traditional roles of white, middle-class femininity?

In Machine Dreams, the depiction of the Mayor's pool party acts as a critical examination of white and middle-class heterosexual dating practices. Danner is thirteen at the time of the party and objects to a symbolic "tailored white shirtwaist with linen cuffs at the short sleeves" (MD 197), which Jean buys for her as if she were to make her début there. The dating system privileged competition and popularity (Bailey 26), and looks were one of the most important assets when women competed to date men. This explains why the older girls pampered themselves by lying in the sun by the pool. Contrary to Gracie's and Mitch's ideas about sun tanning, the older girls cherish their acquired tans, which can be viewed as signs of class privilege (Fraser 112; cf. Ahmed 57-58). Moreover, their exhibitionist behavior seems to be in accordance with Sara Ahmed's feminist notion about tanning as a cultural practice. With this in mind, one can claim that the tans of the older girls signify their whiteness, as their pale complexion enables them to tan in the first place (Ahmed 61). In her analysis of skin as an animated border, Ahmed also suggests that white women tan in order to stress their hierarchical difference and to reinforce a "link between the bronzed body and the erotic," since "[b]lackness is a signifier of sex" (Ahmed 65). Indeed, the sunbathing of the older girls is filled with erotic connotations: "They grew darker and darker, and let a strap fall off one shoulder and show the dead white strip where it had been" (MD 215). Nevertheless, when Danner appears at the party, she catches the attention of the envious older girls and her innocence also attracts the sexually experienced Mayor's son. Frightened by the sexually charged adolescent world, which the pool party represents in miniature, she wants to flee it. This signifies a failure in her reiteration of the discourse of compulsory and constraining white middle-class heterosexuality.

According to performative theory, the normative construction of gender and sexual identity operates through erasures and exclusions (Butler 3, 8, 12). This is also true about the "national" dating conventions which reveal a hierarchical ranking of Americans. Many Americans, such 
as "the very poor and the very rich" and members of ethnic and racial minorities, were excluded from the dating system and its dominant white constructions of masculinity and femininity (Bailey 11). Phillips's narrator underlines this in a passage in which Danner and Billy leave their symbolic dance floor and approach the equally symbolic railroad tracks, where they witness an ugly and alienating episode in which boys from neighboring towns are taking advantage of a girl in a shack. In her innocence, Danner asks if the boys are hurting her. The girl's low social status becomes explicit when a boy answers: "Nah. You can't hurt a girl like her" (MD 223). Like his sister, Billy is subjected to heterosexualizing discourse during the Strawberry Festival. Nevertheless, he is as unprepared as Danner to enact a heterosexual identity. After the boy chases them away, Danner and Billy return to the dance floor and, in an epiphanic scene, demonstrate their close bond by dancing together: "Lights strung on wire above them glimmered, and Billy held one of his hands correctly to the side, as though they kept a breakable object in their clasped hands" (MD 224). While dancing together, Billy and Danner seem to want to escape to an unreal world where no-one recognizes heteronormativity or imposes white middle-class heterosexual identities on them.

In this context, it is important to note that Butler argues that the heterosexual matrix, within which sexual identities are produced, is inherently unstable (see, for instance, Butler 16; Bell 137). However, since the period represented in the depictions of Danner's and Billy's childhood is "an era in which the hetero norm went almost unchallenged" (Katz 96), the only example in the novel of the relaxation of traditional gender roles is found in Jean's recollections about Tom Harwin, her high school boyfriend. He is described as "mannish and independent, but not afraid to be attentive the way a woman would be" (MD 10-11). Tom is not afraid to display personality traits regarded to be feminine. Moreover, he does not shy away from dressing in drag, as Jean tells Danner:

Sure, he fooled around sometimes - once he and Shinner Black dressed in drag on Class Day. Bobby sox, sweaters over C-cup bras stuffed with apples, head scarves, and lipstick. Pretty Peasants, they called themselves, and played it up all during the ceremonies (MD 10).

If hegemonic heterosexuality "is itself a constant and repeated effort to imitate its own idealizations" (Butler 125), the parodic drag act can be 
seen as potentially subversive, to the extent that it "disputes heterosexuality's claim on naturalness and originality" (Butler 125). As we have seen, racial and gendered identities are also classed. In addition to calling into question heterosexualized gender norms, the parody scene destabilizes class differences. This is achieved by portraying how the two crossdressers from different social backgrounds also cross class boundaries. Indeed, in Phillips's novel, one may conjecture about the degree to which the performative possibilities of gender and class flexibility are extinguished by Tom's premature death from heart disease.

While emphasizing that the instability of the heterosexual matrix makes it possible to perform gender differently, Butler also stresses the necessity of an embodied repetition of the norms of idealized masculinity and femininity for maintaining the order of hegemonic heterosexuality (Butler 2, 125). The narration of Danner and Billy's high school years resonates with Butler's argument concerning the role of imitating hegemonic norms in the process of identification and identity formation. In truth, the siblings' respite from the heterosexualizing norms proves to be short, as one chapter later Danner is told to go steady with the popular Riley. A hyperbolic scene in which Riley covers "a path through the garage, and the floor of his white Mustang, with white sheets so that Danner wouldn't dirty the hem of her gown" (MD 247) indicates that he has internalized the old myths of white Southern womanhood. Crucially, Danner's and Riley's white middle-class dating rituals are contrasted with Billy's relationship with Kato. Her background resembles that of Marthella Barnett, and she also represents white trash or what Annalee Newitz and Matthew Wray correctly term "the white Other" in the novel (168). Where Danner is expected to define her morally superior value by acting like a lady, Kato's apparent warmth and spontaneous sexual behavior exclude her from the dating system's ideal of virtuous white middle-class femininity. However, it does not take Danner long to realize that the sort of vacuous feminine identity which she fulfils in her relationship with Riley is a burdensome mask that not only covers her female subordination but also deprives her of sexual self-determination. Realizing that her identity construction is thereby negatively affected, Danner breaks up with Riley. This gives her the possibility of questioning the regulatory sexual norms.

Defying the coherent racial, sexual, gender, and class identity provided 
by a dutiful reiteration of the conservative conventions of dating, Danner exposes herself to a number of new discourses linked to the social movements of the 1960s. An episode at a ministers' conference demonstrates her continuing sensitivity to racism. Later on, Danner is also portrayed teaching disadvantaged pre-school children as part of Project Headstart. Furthermore, her firsthand experience of the hippie movement at college, with its self-proclaimed cthos of pacifism and gender and race equality, proves to be conducive for her continuing search for a mobile and multiple identity reminiscent of postmodern female identity. However, when the family learns that Billy is missing in action in Vietnam, a dominant discourse developed around the war encroaches on the Hampsons' life which seriously limits Danner's process of identity formation. In the context of the Vietnam War, negotiations about a white gendered identity shift to a new level in which a project of remasculinizing of American culture takes place through the discourse of warfare.

\section{Displaced Location and Identity Transformation}

In her landmark study, The Remasculinization of America: Gender and the Vietnam War, Susan Jeffords examines the complex interrelationship between gender and race in literary and cinematic representations of the Vietnam War. As do other scholars, she notes that representations of the war often overcome class, ethnic, and racial barriers (see 54-86). This is also true about Billy's helicopter crew in Vietnam: the other members are a black American, a Texan called Gonzales, and Luke, whose grandmother is Native American. These four men form the only multicultural group of Americans in Machine Dreams. Moreover, the men's relationship is so close that Billy even calls his companions "the only country" (MD 329) he is defending in Vietnam. However, according to Jeffords, the eradication of hierarchical differences in Vietnam narratives is based on collective masculine bonding, which reaffirms masculinity, thereby excluding women and the feminine (xiii). Even if Danner is excluded from the illusory collectivity of Vietnam, her identity process seems to depend on her coming to terms with the war. Like Sam Hughes - the protagonist in Bobbie Ann Mason's novel In Country (1985) - who yearns to 
restore a link with her father who has died in Vietnam, Danner tries to establish a connection with her brother after his helicopter has been shot down. She attempts to contact the surviving African American and Luke's Osage grandmother, but her failure lends credence to Jeffords's argument that women are not at any point included as part of the multiracial collectivity in Vietnam (59).

In her analysis of Vietnam narratives by contemporary American women authors, Maureen Ryan observes that the female protagonists, who are excluded from the "brotherhood" created in battle, have a crucial bond with their own brothers (45). Just like Danner, the other female protagonists discussed by Ryan are older siblings, who have tried to protect their younger brothers in childhood. As with Danner, who urged her brother to flee to Canada in order to escape the draft, they also attempt to save their brothers from the war (Ryan 45). Denying the possibility that Billy may be dead, Danner does her utmost to find him. At the same time, she tries to identify with her lost brother and to appropriate his war experiences. She participates in veterans' activities, for example, where she becomes sexually involved with several angry and frustrated veterans. These desperate short-term relationships, which remind the reader of Danner's experimentation with drugs, demonstrate her misguided need to rebel against the traditional parameters of virtuous white middle-class femininity. Moreover, given the depth of Danner's grief, her fragile new identity formation is shown to be traumatized to such an extent that she no longer understands her own reactions. Indeed, the new narrative solution whereby the self-destructive Danner ultimately accepts the conventional Riley as her saviour would remain inexplicable if it were not for the discursive ambivalence that makes Danner yearn for the stability of her high school years in the midst of her great confusion.

The hierarchical structure of representations of Vietnam reinforces masculine dominance and traditional gender roles. Danner acknowledges the likelihood of Billy's death while in therapy, but she focuses exclusively on the victim status of the white male in Vietnam. In doing this, she unwittingly participates in what Jeffords calls "the remasculinization of America." According to her, the cultural project of winning victim status for the white male can be partly seen as a reaction to the gains made by women and minorities through legislative or federal action (Jeffords xi-xii, xiv; Carton 297). Moreover, Jeffords claims that, instead of 
leading to a reexamination of the U.S. value system, the representations of Vietnam studied by her present the soldiers/veterans not as oppressors but as victims of their own weak and indecisive government (xiv, 116143). In Machine Dreams, Danner also blames the government and even considers living in permanent exile. Instead, she moves to California, the birth place of 1960 s West Coast counterculture, where she decides that she will never leave the country, because: "My parents are my country, my divided country" (MD 368). Her parents' divorce challenges the performed nature of families, and is metaphorically linked to the divided country. Thus Danner not only questions the legitimacy of the dominant national narrative, but also points to the internal contradictions and splits within the country. According to Homi K. Bhabha, the divided and split nation may become a liminal signifying space, which is internally marked by "the affective experience of marginality" $(148,172)$. Compared to Bellington, Danner's new displaced location on "the far frontiers" (MD 368), where she arrives "like a refugee" (MD 367), is evocative of such a liminal space, which is favorable for the emergence of alternative, heterogeneous identity formations and thereby presages her renegotiation of identity.

As I have argued earlier in this article, Danner's wish to go to California is originally linked with the possibility of acquiring an open, fluid, and mobile identity, which is characteristic of postmodern female identity. In her article, Ryan concludes that "Machine Dreams ends with Danner's recognition of her failure" to protect Bill and "to declare her own separate peace" (49). However, the brief concluding chapter, entitled "Machine Dream," foregrounds Danner's need to break free from the grip of her arrested mourning. It thereby offers a creative response to trauma and an alternative interpretation of the novel. Mitch and Billy are fascinated with machines throughout Machine Dreams, which signify masculinity and power, whereas Danner's yearning for an empowering mobile identity is indicated by magic horses. ${ }^{5}$ Two of the mottos of the novel refer to Pegasus, which contemporary mythology associates with pocts and poctic inspiration. This suggests that the horses Danner dreams 
about are related to her role as the family member who pieces together scattered family memories.

In their book on storytelling, Kristin M. Langellier and Eric E. Peterson emphasize that, "[a]s a human communication practice, performing narrative combines the performative 'doing' of storytelling with what is 'done' in the performance of the story" (2). As if echoing this statement, Danner contends: "After all, I am in the stories. I'm here, relating the stories to the present and to the future, and I am always looking for hints" (MD 344). While doing this, Danner imaginatively transforms family stories into narrative performance, which both constructs and deconstructs the rituals of normative family storytelling and simultaneously helps to transform relations of identity and difference in a way that may contribute to change. ${ }^{6}$ Even if Danner's new identity remains highly problematic, the power of storytelling may help her to construct a destabilized, heterogeneous female identity, which invokes postmodern conceptions of processual female identities open to transformation and reinscription.

However, instead of generating magical transformations and limitless possibilities for alternative identity constructions, Machine Dreams challenges us to reexamine the ways in which the multiple and intersecting nature of identity formation is constrained by the regulatory norms imposed by the dominant society. As my analysis of Danner's process of identity formation indicates, restrictive societal definitions are further implemented by the nuclear family construct, as well as by the social controls exerted by the hierarchical structure of small-town America. This entails that the privileged white middle-class identities, which are performatively produced within the context of these power relations, constantly cite and reiterate sedimented heterosexual gender ideals. These concepts are not only reinforced by outdated white myths but also by other gendered conventions, such as the rituals of the modern white middle-class dating system. In drawing attention to the power differences among whites, while still employing stereotyped depictions to delimit the borders of white middle-class identity, the novel helps to challenge and destabilize essentialized notions of white female identity. With her questioning of dominant gender, class, and racial norms, Danner explores the 
productive instabilities inherent in the process of discursive reiteration, but the novel also insists on the possibility of her being able to vary her performance of white female identity. Feminist configurations of postmodern identity formations interrogate and resist complex operations of power, thereby opening up future possibilities. By its implicit critique of inequal social relations, Machine Dreams ultimately charts Danner's perennially deferred, yet continual, process of constructing a more viable female identity grounded in the possibility of social transformation.

\section{Bibliography}

Aanerud, Rebecca. "Fictions of Whiteness: Speaking the Names of Whiteness in U.S. Literature." Displacing Whiteness: Essays in Social and Cultural Criticism. Ed. Ruth Frankenberg. Durham: Duke University Press, 1997. 35-59.

Ahmed, Sara. "Animated Borders: Skin, Colour and Tanning." Vital Signs: Feminist Reconfigurations of the Biollogical Body. Eds. Margrit Shildrick and Janet Price. Edinburgh: Edinburgh University Press, 1998. 45-65.

Bailey, Beth L. From Front Porch to Back Seat: Courtship in Twentieth-Century America. Baltimore: The Johns Hopkins University Press, 1989.

Bell, Vikki. "Mimesis as Cultural Survival: Judith Butler and Anti-Semitism." Performativity \& Belonging. Ed. Vikki Bell. London: SAGE Publications, 1999. 134-61.

Bhabha, Homi K. The Location of Culture. London: Routledge, 1995.

Boose, Lynda E., and Betty S. Flowers. "Introduction." Daughters and Fathers. Eds. Lynda E. Boose and Betty S. Flowers. Baltimore: The Johns Hopkins University Press, 1989. 1-14.

Bordo, Susan."Feminism, Postmodernism, and Gender-Scepticism." Feminism/Postmodernism. Ed. Linda J. Nicholson. New York: Routledge, 1990. 133-56.

Butler, Judith. Bodies That Matter: On the Discursive Limits of "Sex." London: Routledge, 1993.

Carby, Hazel W. Reconstructing Womanhood: The Emergence of the Afro-American Woman Artist. Oxford: Oxford University Press, 1987.

Carton, Evan. "Vietnam and the Limits of Masculinity." American Literary History 3.2 (1991): 294-318.

Chambers, Deborah. Representing the Family. London: SAGE Publications, 2001.

Clark, Michael. "Remembering Vietnam.” Cultural Critique, 3 (Spring 1986): 46-78.

Frankenberg, Ruth. "Introduction: Local Whitenesses. Localizing Whiteness." Displacing Whiteness: Essays in Social and Cultural Criticism. Ed. Ruth Frankenberg. Durham: Duke University Press, 1997. 1-33.

Fraser, Mariam. "Classing Queer: Politics in Competition." Performativity and Belonging. Ed. Vikki Bell. London: SAGE Publications, 1999. 107-31. 
Fraser, Nancy, and Linda J. Nicholson. "Social Criticism without Philosophy: An Encounter between Feminism and Postmodernism." Feminism / Postmodernism. Ed. Linda J. Nicholson. New York: Routledge, 1990. 19-38.

Godden, Richard. "No End to the Work? Jayne Anne Phillips and the Exquisite Corpse of Southern Labor." Journal of American Studies 36.2 (2002): 249-79.

Hobson, Fred. The Southern Writer in the Postmodern World. Athens, Georgia: U of Georgia P, 1991.

Hofmann, Bettina. Ahead of Survival: American Women Writers Narrate the Vietnam War. Frankfurt am Main: Peter Lang, 1996.

Jarvis, Brian. "How Dirty Is Jayne Anne Phillips?" Yearbook of English Studies 31 (2001): 192-204.

- Postmodern Cartographies: The Geographical Imagination in Contemporary American Culture. London: Pluto Press, 1998.

Jeffords, Susan. The Remasculinization of America: Gender and the Vietnam War. Bloomington: Indiana University Press, 1989.

Jones, Anne Goodwyn. "Women Writers and the Myths of Southern Womanhood." The History of Southern Women's Literature. Eds. Carolyn Perry and Mary Louise Weaks. Baton Rouge: Louisiana State University Press, 2002. 275-89.

Katz, Jonathan Ned. The Invention of Heterosexuality. Foreword by Gore Vidal. New York: Plume, 1996.

Kuhn, Annette. "A Journey through Memory." Memory and Methodology. Ed. Susannah Radstone. Oxford: Berg, 2000. 179-96.

Langellier, Kristin M., and Eric E. Peterson. Storytelling in Daily Life: Performing Narrative. Philadelphia: Temple University Press, 2004.

Lloyd, Moya. Beyond Identity Politics: Feminism, Power \& Politics. London: Sage Publications, 2005.

May, Elaine Tyler. Homeward Bound: American Families in the Cold War. N.p. Basic Books, 1999.

Newitz, Annalee, and Matthew Wray. "What Is 'White Trash'? Stereotypes and Economic Conditions of Poor Whites in the United States," Whiteness: A Critical Reader. Ed. Mike Hill. New York: New York University Press, 1997. 168-84

Phillips, Jayne Anne. Machine Dreams. New York: Pocket Books, 1985.

Roediger, David R. The Wages of Whiteness: Race and the Making of the American Working Class. London: Verso, 1991.

Ryan, Maureen. "The Other Side of Grief: American Women Writers and the Vietnam War." Critique 34.1 (1994): 41-57.

Seidel, Kathryn Lee. "Myth of Southern Womanhood in Contemporary Literature." The History of Southern Women's Literature. Eds Carolyn Perry and Mary Louise Weaks. Baton Rouge: Louisiana State University Press, 2002. 429-38.

Simon, Bryant. "NNew Men in Body and Soul': The Civilian Conservation Corps and the Transformation of Male Bodies and the Body Politic." Gender and the Southern Body Politic. Ed. Nancy Bercaw. Jackson: University of Mississippi Press, 2000. 131-60.

Welter, Barbara. "The Cult of True Womanhood: 1820-1860." American Quarterly 18.2 (1966): 151-74.

Whisnant, David E. Modernizing the Mountaineer: People, Power and Planning in Appalachia. Knoxville: The University of Tennessee Press, 1994. 
Wright, Elizabeth. "Modern Psychoanalytic Criticism." Modern Literary Theory: A Comparative Introduction. Eds. Ann Jefferson and David Robey. London: B.T. Batsford, 1986. 145-65.

- Psychoanalytic Criticism: Theory in Practice. London and New York: Methuen, 1984. Yaeger, Patricia. Dirt and Desire: Reconstructing Southern Women's Writing, 1930-1990. Chicago: The University of Chicago Press, 2006. 